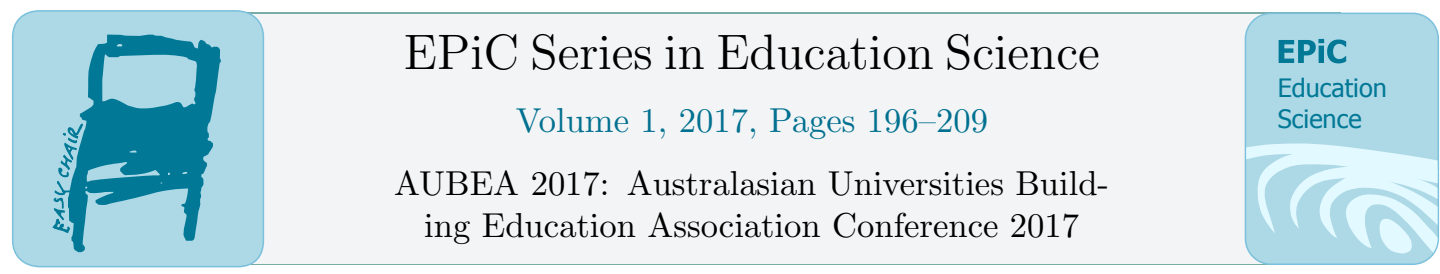

\title{
FOSTERING STUDENT WORK READINESS - A UNIVERSITY CASE STUDY
}

\author{
J. Borg ${ }^{1}$, M. Turner ${ }^{2}$, C. Scott-Young ${ }^{2}$ \\ ${ }^{1} \mathrm{PhD}$ Student, RMIT University \\ ${ }^{2}$ Senior Lecturer, RMIT University
}

jessica.borg@rmit.edu.au

\begin{abstract}
Student work readiness relates to the acquisition of relevant skills and knowledge which enable students to make meaningful contributions to industry, and assist them in their transition from student to practitioner. An individual's smooth transition into the workforce translates into higher levels of interactions in their workplace, ensuing in benefits for both the employee and the employer. In the built environment, employees are known to experience high levels of work-related stress, exacerbating the need for built environment professionals to be well prepared for the workforce. While work readiness is typically reserved for graduates who have completed their program of study, there has been a notable increase in built environment undergraduates combining work and study prior to graduation. This trend challenges universities to consider that these students need to be work ready prior to completion of their studies. Research notes that student work readiness can be attained through collaboration between universities, students and industry. This study uses the newly conceptualised work readiness model, known as The Life Buoy
\end{abstract}


model, to explore the ways in which one Australian university collaborates with industry to i.) foster the development of work ready characteristics in built environment students; and, ii.) apply university-based initiatives to underpin the development of work ready characteristics. Analysis of course-related documents classified work readiness initiatives at the university into the eight components of the Life Buoy model, suggesting that it may be a useful framework to guide universities to better work with industry in designing and assessing their work ready initiatives.

Keywords: built environment, industry involvement, student perspective, university initiatives, work readiness.

\section{INTRODUCTION}

\section{Work readiness as an industry wide objective}

Work readiness is a graduate attribute that is typically used in reference to graduates who have completed their studies and have commenced their professional career in industry. Literature has been found to describe work readiness as a concept with different labels, including: work preparedness, graduate employability, transferable skills, key competencies, and generic attributes (Nettleton, Litchfield \& Taylor, 2008; Caballero \& Walker, 2010). Work readiness has been identified as an area of escalating interest to employers world-wide. Furthermore, with reference to the changing nature of the workplace, research has identified that "the extent to which graduates are 'work ready' is seen as indicative of their potential in terms of job performance and career advancement" (Caballero \& Walker, 2010: 13). Thus, preparing work ready graduates can be seen as an industry wide objective. Furthermore, a smooth transition into the work environment is interrelated with higher levels of interaction, mutual support in the workplace, and a significant reduction in staff turnover (Argyle, 1989). A work ready individual is one that is equipped to make a successful transition into the workforce, thus is able to make a positive contribution to his/her new organisation, employer and industry at large. 


\section{Work readiness in the context of the built environment}

While work readiness is typically reserved for students who have successfully completed their program of study and are entering the workforce, studies indicate that students in the built environment are combining work and study (Curtis \& Williams, 2002). Studies have found that hours and effort spent by undergraduate built environment students in paid employment were at the very least, as long as the hours spent at university (Forsythe and Zou, 2006; Lingard, 2005). Combining work and study comes with inherent benefits for students; students who combine work and study have been found to develop transferable employability skills including organisational, interpersonal and time management skills (Watts \& Pickering, 2000). However, these findings that show more students are combining work and study, challenge the understanding that work readiness is a concept to be reserved for graduates, as the work readiness requirements of this emerging student cohort who combine work and study need to be catered to prior to graduation. The student cohort undertaking paid work while completing their degree presents a new challenge for universities; these students call for work readiness prior to graduation. Savage, Davis and Miller (2010:103) found that "university plays a crucial role in ensuring graduates develop lifelong learning skills and attributes that can carry them onto a long and fruitful career, however, professionals and students did not feel universities were doing enough to ensure this development occurred". While universities are recognised as having a primary role in fostering work readiness in graduates, it has been debated whether the educational institutions are the principal places for students to gain employability skills (Cranmer, 2006).

\section{Universities: Trying to foster work readiness in students}

The call for work ready graduates is felt globally. In Australia, the rates of graduates finding employment are relatively high at $75 \%$ and above, yet studies highlight that employers are not satisfied with aspects of student work readiness. Employers advocate for the integration of practical skill development into university programs, believing that a closer alignment between graduate work readiness and desired employability skills would ensue as a result (Cavanagh, Burstone \& Southcombe, 2015). This concern that university programs are not producing work ready graduates is not a new 
concept and one that is not merely confined to Australia. In their research seventeen years ago, De la Harpe, Radloff and Wyber (2000) suggested that there is concern world-wide that students are graduating from their university programmes without the skills necessary for their future careers. This highlights an existing discrepancy between the definition and understanding of the concept of work readiness from academic and industry perspectives, placing the students in a position where the skills taught to them at university to prepare them for the workforce are not in alignment with the demands of their employers in the respective industry.

Cranmer (2006) argued that universities may not be the prime places for stimulating graduate employability, and highlighted that universities and academics need to accurately decipher the demands of the labour market. It has been recommended that universities should encourage more involvement from industry in the selection and development of employability criteria (Mason, Williams \& Cranmer, 2009). Universities of Australia along with the Business Council of Australia, the Australian Chamber of Commerce and Industry, the Australian Collaborative Education Network and the Australian Industry Group recently signed a Statement of Intent; one of the four main objectives of the statement was to improve the work readiness of university graduates. It becomes evident that the concept of preparing students to be work ready graduates has been identified as an area in need of improvement. The involvement of industry practitioners and employers in academia and university curriculum design is not a new concept. However, while the benefits of combining the forces of industry and academia to cater to the work readiness requirements of students is recognised, there still remains a lack of industry involvement in the development of university curricula.

\section{Incorporating work readiness into educational pedagogy}

Graduate employability has long been an important consideration for educators, employers and students. Some of the common methods of preparation for work readiness entail collaboration between universities and industry. These include: industry placements, shadowing, internships, and a year-out-in-industry component in degree programs. However, it must be noted that while student work 
readiness is highly valued by universities and appraised by employers, few models for preparing work ready students can be found in the existing literature. In recent research, Cavanagh, Burstone and Southcombe (2015), found that to prepare work ready students, university curricula should be designed by universities through corroboration both with industry employers and the students themselves. Moreover, research indicates that work readiness is to be incorporated into current day educational pedagogy (Banadaranaike \& Willison, 2015). Smith et al. (2014) highlighted research which makes a contribution to the pedagogy of teaching, as a high priority to higher education teaching in Australia. Banadaranaike and Willison (2015) asserted that work readiness and employability skills are a product of one's cognitive and emotional skills; their research concluded that "educational pedagogy therefore needs to incorporate new ideas in the curriculum to benefit students and build a better rapport with industry and the community to create a more sustainable workforce for the future" (p.11). It is evident that educational pedagogy should incorporate the concept of work readiness to reflect the needs to equip the workforce of the future, yet there is little to no recommendations as to how this can be realised.

\section{The Life Buoy Model}

The Life Buoy Model proposed by Borg and Turner (2016) differs from other models that map employability skills in that it was a student-led model, designed to aid universities and students to identify the components needed to feel work ready, and ultimately, to enable students to combat the fear of being thrown in the deep end. Furthermore, the model extends to industry corroboration, in that it presents university based initiatives to foster work readiness in students which can only be realised with successful collaboration with industry professionals and the industry at large. Borg and Turner's (2016) model incorporates eight mutually exclusive components. These are broken down into i) four work ready characteristics required by students and ii) four university based initiatives which underpin the development of work ready characteristics. Furthermore, the model can be used to suggest means through which universities can work with industry to cater for the development of work readiness in their students. 


\section{RESEARCH AIM}

This research uses the newly conceptualised work readiness model, known as The Life Buoy Model, to explore the ways in which one Australian university fosters the development of work ready characteristics in built environment students.

\section{METHODOLOGY}

The research adopted a case study approach and focused on the School of Property, Construction and Project Management (PCPM) at a large Australian metropolitan university. The sample was constrained to the initiatives available for students completing any one of three undergraduate programs in the selected School. Documents relating to the work readiness of students in any one of the three programs in the School were collected, consistent with the understanding that the identity of a university can be defined through its documents (Owen, 2014); it was held that documents from the selected university would provide insight into the work readiness initiatives of the university. The data took the form of: student course guides, student program handbooks, course learning outcomes, career newsletters and online sources via the university website. Documents were analysed using the directed content analysis technique. When implementing this approach, "the analysis starts with a theory or relevant research findings as guidelines for initial codes" (Hsieh \& Shannon, 2005:1277). The eight components of the Life Buoy Model served as the eight codes against which the initiatives were categorised. These are: self-confidence, sufficient preparation, smooth transition, solid foundation, sufficient work integrated learning, staff with industry experience and support systems. Once coded, the documents were further analysed to explore how the initiatives referenced in the documents contributed to the attainment of the Life Buoy work readiness component against which it was coded. 


\section{RESULTS}

The results categorised all university initiatives available to students within the School of PCPM into the eight components of the Life Buoy Model. Table 1 depicts each of the components of the Life Buoy Model and ranks them in order of frequency by which they featured in the documents analysed.

Table 1. Ranking of Life Buoy Model Components by documented frequency.

\begin{tabular}{|c|l|c|}
\hline Rank & Life Buoy Model Component & $\begin{array}{l}\text { Frequency } \\
\text { (By no. of times of } \\
\text { appearance) }\end{array}$ \\
\hline 1 & Solid WIL \& Solid Foundation & 7 \\
\hline 2 & Support Systems \& Smooth Transition & 6 \\
\hline 3 & $\begin{array}{l}\text { Strong Links to Industry \& Sufficient } \\
\text { Preparation }\end{array}$ & 5 \\
\hline 4 & Self Confidence & 3 \\
\hline 5 & Staff with Industry Experience & 2 \\
\hline
\end{tabular}

The way in which the School of PCPM fosters the development of work ready characteristics in students in accordance with the components of the Life Buoy Model is as depicted in Table 2:

Table 2. Work readiness initiatives in place at the School of PCPM. 


\begin{tabular}{|c|c|}
\hline $\begin{array}{l}\text { Life Buoy } \\
\text { Model } \\
\text { Component }\end{array}$ & $\begin{array}{l}\text { Initiatives in place at the School of PCPM at the selected } \\
\text { University: }\end{array}$ \\
\hline Self-Confidence & $\begin{array}{l}\text { - Peer assisted learning programs to facilitate the dissemination of } \\
\text { knowledge among students and develop students' academic confidence } \\
\text { (e.g. The Peer Assisted Learning Program is led by student mentors and } \\
\text { is based upon the dissemination of knowledge among students). } \\
\text { - Specific services to aid students to develop employability skills to } \\
\text { increase self-confidence when sourcing employment (i.e. The Careers } \\
\text { Toolkit is available to all students at the university; it is an online } \\
\text { platform providing information to students regarding how to plan their } \\
\text { career, apply for a job and make themselves employable. }\end{array}$ \\
\hline $\begin{array}{l}\text { Sufficient } \\
\text { Preparation }\end{array}$ & $\begin{array}{l}\text { - Keeping the students informed about current trends in industry through } \\
\text { newsletters, blogs, correspondence (i.e. The School of PCPM has an } \\
\text { official Facebook page and PCPM School News Blog). } \\
\text { - Industry mentoring programs to facilitate engagement between industry } \\
\text { employers and students (i.e. Employer of Choice Program and Industry } \\
\text { Mentoring Program. Both programs encourage engagement between } \\
\text { students and professionals within the specific field which the student } \\
\text { aspires to enter into). } \\
\text { - Hosting of career days and similar events to bring prospective employers } \\
\text { to engage directly with the students (e.g. The School hosts } 2 \text { Career Days } \\
\text { per year). }\end{array}$ \\
\hline $\begin{array}{l}\text { Smooth } \\
\text { Transition }\end{array}$ & $\begin{array}{l}\text { - Provision of networking opportunities for students to interact with } \\
\text { industry professionals (i.e. The networking opportunities offered } \\
\text { through the Employer of Choice Program enables the students to engage } \\
\text { with potential future employers). } \\
\text { - Career platforms through which students are able to search for } \\
\text { employment opportunities (i.e. Careers Toolkit and Careers Hub are } \\
\text { online platforms available to all students at the university). } \\
\text { - Career help/resources to provide information for career planning (e.g. } \\
\text { Students have access to careers counsellors). }\end{array}$ \\
\hline Solid Foundation & $\begin{array}{l}\text { - Delivery of core courses within programs to cover the knowledge } \\
\text { required for successful performance in the envisaged profession (i.e. The } \\
\text { PCPM programs mandate the completion of } 32 \text { courses; } 3 \text { electives and } \\
29 \text { core units). } \\
\text { - Having accredited programs (i.e. The PCPM programs are recognised } \\
\text { by the world-wide institution - the Royal Institute of Chartered } \\
\text { Surveyors). }\end{array}$ \\
\hline $\begin{array}{l}\text { Solid Work } \\
\text { Integrated } \\
\text { Learning (WIL) }\end{array}$ & $\begin{array}{l}\text { - Offer Work Integrated Learning courses within the programs. (i.e. The } \\
\text { PCPM programs offer at least } 1 \text { WIL course which encompasses guest } \\
\text { lectures, industry mentors and industry panels). }\end{array}$ \\
\hline
\end{tabular}




\begin{tabular}{|c|c|}
\hline $\begin{array}{l}\text { Staff with } \\
\text { Industry } \\
\text { Experience }\end{array}$ & $\begin{array}{l}\text { - Having teaching staff with real industry experience (i.e. The university } \\
\text { attributes its industry-aligned programs to having many of its teaching } \\
\text { staff work with industry, community and businesses). }\end{array}$ \\
\hline $\begin{array}{l}\text { Strong Links to } \\
\text { Industry }\end{array}$ & $\begin{array}{l}\text { - Annual industry nights to serve as networking events for students, staff } \\
\text { and industry professionals (i.e. The School hosts an Annual Industry } \\
\text { Night to recognise the achievements of its students; awards are } \\
\text { sponsored by industry professionals). } \\
\text { - Awards and scholarships sponsored by industry professionals to } \\
\text { recognise the achievements of students within the university. }\end{array}$ \\
\hline Support Systems & $\begin{array}{l}\text { - Industry mentoring programs through which students can be connected } \\
\text { to professionals in the field which they aspire to gain employment in (i.e. } \\
\text { The PCPM Mentoring Program pairs students in their penultimate or } \\
\text { final year with mentors in industry). } \\
\text { - Provision of additional support systems (i.e. Students have access to the } \\
\text { university Counselling Service). }\end{array}$ \\
\hline
\end{tabular}

\section{DISCUSSION}

The results indicated that all university initiatives available to students within the School of PCPM could be categorised into the eight components of the Life Buoy Model. In effect, the results reaffirmed the viability of the Life Buoy Model as a framework against which universities may wish to plan and design their work readiness initiatives. This suggests that the Life Buoy Model may serve as one of the new and applicable methodologies that Hager and Holland (2006) recommended universities look towards implementing to provide their graduates with the work readiness competence.

Self-confidence: The results demonstrate that universities can develop Self-Confidence by implementing a number of practices. These may entail offering peer assisted learning thereby increasing confidence in academic learning. In addition, universities may be able to offer courses through which students can gain employability skills sought after in industry. It is envisaged that by universities making such services available to students, educational institutions may be able to increase students' confidence in their ability to contribute to the workplace, a trait that was identified in Knight and Yorke's (2003) research. 
Sufficient preparation: The results demonstrate that universities can foster Sufficient Preparation by informing students of the recent news related to industry. Furthermore, universities can ensure that the students are well connected to industry through mentoring programs, which encourage engagement between students and professionals within the specific field which the student aspires to enter into. In addition, universities may look towards bringing prospective employers to the School to engage directly with the students and share with them their knowledge of the opportunities and challenges within their industry, thereby preparing the students for what awaits them in industry.

Smooth transition: The results demonstrate that universities can facilitate a Smooth Transition by offering networking opportunities that enable the students to engage with their potential future employers. Universities may look towards providing career services, which help students to plan their careers. Universities may be able to offer an avenue for students to search for employment and internship opportunities which can aid students to explore career planning issues. It is envisioned that by aiding students in their transition to industry, universities may be able to alleviate the number of students who may experience reality shock, as identified by Kramer (1974).

Solid foundation: The results demonstrate that universities can provide a Solid Foundation by having clear learning/teaching areas, industry connections and career outlooks for students. Hager and Holland (2006) highlighted the misassumption often made by tertiary students that academic skill sets are identical to skill sets required in the workforce/industry. To expose students to the skills valued by industry, universities can have programs that are accredited by industry institutions, such as the Royal Institution of Chartered Surveyors' accreditation that is recognised world-wide.

Solid work integrated learning: The results demonstrate that universities can provide Sufficient Work Integrated Learning by offering core courses which address WIL components. Universities may look towards offering core courses which encompass the WIL 
components of guest lecturers and industry mentors. The importance of universities' capacity to offer WIL opportunities for their students is clear; studies have found that students who engage in Work Integrated Learning are better placed to find employment within their chosen field (Orrell 2004).

Staff with industry experience: The results demonstrate that universities can provide Staff with Industry Experience by employing staff with suitable academic qualifications coupled with relevant work experience in industry, community organisations or business. It is recognised that having teaching staff with industry experience "leads to a better industry and university relation" (Idrus, Dahan \& Abdullah 2013, pp.1).

Strong links to industry: The results demonstrate that universities can develop Strong Links to Industry by organising events which give students the opportunity to connect with professionals within their prospective industries. Mason, Williams and Cranmer (2009) recommended that universities should encourage more involvement from industry in the development of employability criteria. Universities can endeavour to provide a platform which can be used by employers to communicate their requirements of employability criteria to students.

Support systems: The results demonstrate that universities can provide Support Systems by offering careers counselling services as well as general counselling whereby students may seek counselling support for issues such as: stress and lack of motivation to study. The transition from university to industry can prove extremely stressful for students (Davis 2010). Furthermore, research has found that employees in the built environment industry tend to experience high levels of stress (Love et al., 2010). Hence, it is essential that students are able to rely on relevant support systems being available to them at their universities.

\section{CONCLUSION}

This study analysed the initiatives used by one Australian university to foster the development of the work ready skills of emerging Built 
Environment professionals. Through exploring the application of the conceptual Life Buoy Model, this research extends theory by providing an understanding of the real-life application of the eight components of the model to foster work readiness. While the findings of the study cannot be generalised due to the single case study, the results can serve as a basis from which other universities may wish to design and plan their work readiness initiatives. As work readiness within the built environment remains an area where little research has been undertaken, the next stage of the research seeks to further explore the concept from different stakeholder perspectives. Given the global concern about new graduates being inadequately equipped to thrive in the workforce, it is envisaged that this research will have benefits for students, universities and employers world-wide and that the benefits of this research transcend past the built environment industry.

\section{REFERENCES}

Argyle, M.(1989)"The social psychology of work". 2ed.Wisconsin: Penguin.

Bandaranaike, S. and Willison J. (2015) Understanding emotional work readiness in the workplace. "19th WACE World Conference on Cooperation \& Work-Integrated Education", 18-21 August 2015, Kyogo Sangyo University, WACE Advancing Cooperative \& Work-Integrated Education.

Borg, J. and Turner, M. (2016) "Thrown in the deep end: Workreadiness in the built environment". In "40th AUBEA Conference", 6-8 July 2016, Australasian Universities Building Education Association, Central Queensland University, North Rockhampton QLD,6-8 July 2016, 78-88.

Caballero, C. and Walker, A. (2010) Work readiness in graduate recruitment and selection: A review of current assessment methods. "Journal of Teaching \& Learning for Graduate Employability",1,13-25.

Cavanagh, J., Burston, M., Southcombe, A. and Bartram, T. (2015) Contributing to a graduate-centred understanding of work readiness: An exploratory study of Australian undergraduate 
students' perceptions of their employability. "The International Journal of Management Education", 13, 278 - 288.

Cranmer, S. (2006) Enhancing graduate employability: best intentions and mixed outcomes. "Studies in Higher Education", $31(2), 169-184$.

Davis, G.J. (2010) "The perceptions of recent business graduates of the transition experience from the collegiate environment to the work environment". PhD thesis, University of North Florida, Florida.

De la Harpe, B., A. Radloff and J. Wyber, 2000, "Quality and generic (professional) skills". Quality in Higher Education, 6(3): 231- 243.

Forsythe, P. and P. Zou, 2006, "Improving student satisfaction in undergraduate construction management studies". Proceedings of the Australian Universities Building Education Association Annual Conference, July, 2006, Sydney.

Hager, P. and Holland, S. (2006) Nature and development of generic attributes, In: P. Hager, \& S. Holland (eds.) "Graduate attributes, Learning and Employability", Dordecht: Springer.

Hsieh, H. and Shannon, S. (2005) Three Approaches to Qualitative Content Analysis. "Qualitative Health Research", 15(9), 12771288.

Idrus, H., Dahan, $H$ \& Abdullah, $N$ 92013). Bringing Industry Practitioners On Board: The Way Forward, $6^{\text {th }}$ International Conference on University Learning and Teaching (InCULT 2012).

Knight, P.T. and Yorke, M. (2003) Assessment, Learning and Employability, McGraw-Hill Education: Berkshire.

Kramer, M. (1974) "Reality Shock: Why Nurses Leave Nursing", The C.V. Mosby Company: Saint Louis.

Lingard, H. (2005) Balancing study and paid work: The experiences of construction undergraduates in Australia. Australian Journal of Construction Economics and Building, 5, 41-47.

Litchfield, A., Frawley J., and Nettleton, S. (2010) Contextualising and integrating into the curriculum the learning and teaching of work-ready professional graduate attributes. "Higher Education Research \& Development", 29, 519-534. 
Love, P. E. D., Edwards D. J. and Irani, Z. (2010) Work stress, support, and mental health in construction. "Journal of Construction Engineering Management", 136, 650-658.

Mason, G., Williams, G., and Cranmer, S. (2009) Employability skills initiatives in higher education: what effects do they have on graduate labour market outcomes? "Education Economics", $17(1), 1$ - 30.

Orrell, J. (2004) "Work integrated learning programmes:

Management and educational quality". An Australian University Quality Audit (AUQA) Occasional Publication, Proceedings of the Australian Universities Quality Forum 2004.

Owen, G. (2014) "Qualitative Methods in Higher Education Policy Analysis: Using Interviews and Document Analysis". The Qualitative Report, 19 (article 52), 1-19.

Savage, S., R. Davis and E. Miller, 2010, Professional Education in Built Environment and Design: Final Report, Australian Learning and Teaching Council: Canberra.

Smith, C., Ferns, S., Russell, L. and Cretchley, P. (2014) "The impact of work integrated learning on student workreadiness". Office for Learning and Teaching, Sydney, viewed $1^{\text {st }}$ May 2016 <http://hdl.voced.edu.au/10707/337518>.

Watts, C. and A. Pickering, 2000, "Pay as you learn: student employment and academic progress". Education and Training, 42: $129-134$. 